\title{
Kosovo - Constitutional Rights and Their Abuse in the Totalitarian Yugoslav State(1981-1990)
}

\author{
Haki Kabashi ${ }^{1}$
}

\begin{abstract}
In the Constitution of the Socialist Republic of Yugoslavia of 1974, from its preamble and to the last of its article, theoretically the rights and freedoms of its citizens are defined satisfactorily. These freedoms and constitutional rights, especially after the year of 1981 (march demonstrations in Kosovo) have been violated and abused in the worst possible manner by the state institutions of the Yugoslav Federation, particularly when Kosovo's Albanians where in question. George Orwell, in the "Animal Farm" wrote that the rights existed but they do not apply to everyone. Although 1981 is considered the year that put Kosovo in the map of "hot countries", this year is considered the year of the commencement of violence, horror and terror on the Yugoslav-Serb state that ended with the death of over 14,000 citizens and with over 2000 missing from the 1998-99 war.

Throughout this period, Kosovo's Albanians experienced prosecution, arrests, isolation and imprisonment without trials, poisoning of the students and youth and executions committed without a law by the police. The Yugoslavian military also begun to murder young cadets on their constitutional service who then where returned home on coffins diagnosed as suicides. The South African segregation was applied also to Kosovo's Albanians on employment, education, health, culture and sport. Simply put this year is recognized as the Dark Year for Kosovo's Albanians as a result of the forms of repression and state terror that had begun and lasted until the $10^{\text {th }}$ of June 1999, when it definitely leaves Kosovo.
\end{abstract}

Keywords: Kosovo, demonstrations, constitution, murder, Yugoslavia

\section{Introduction}

My interest on studying this relatively long period of time consists on the need for the evil not to become subject of forgetfulness, that everything that took place in the name of defending Yugoslavia and the "endangerment of the constitutional order" from Albanian irredentism throughout the last two decades of the century past. For the purpose of this study we have used the analysis and comparative methods thus giving the reader the ability to have a clear overview of the events that begun with the maxima of "defending the country and the Yugoslavian brotherhood and unity" and evolved afterwards onto a terrifying war between "brothers", with an aftermath consisting on the death of hundreds of thousands of citizens from different nationalities. According to data from different local studies and international institutions it appears that the constitutional rights existed on paper, meanwhile their application was selective. Even the constitutional requests exercised from its citizens from Kosovo where considered nationalist, irredentist and where concluded with arrests and different violations by the state institutions, police, special police units and the JAN (Yugoslav People's Army) who was used against its clear constitutional designation to suppress, violate and kill protesting citizens in the streets of Kosovo for equality in the common state of Yugoslavia. Unfortunately the (miss) use and the involvement of this army in political 
deals brought the largest bloodshed in the territories of ex-Yugoslavia. Also on this study we used the statistical data that are drawn from different sources that talk for flagrant violations of the human rights and freedoms in Kosovo for the period in question.

\section{Prosecution and persecution for the rights guaranteed by the Constitution}

According to the preamble of the 1974 Constitution of the Socialist Federal Republics of Yugoslavia it follows "Given the fact that the workers and the peasants and the progressive people of all nationalities of Yugoslavia united in the front of National Liberation with the Communist Party leading, with its National Liberation war and the socialist revolution overthrew the old class order based in exploitation, political oppression, national inequality and begun to establish a society where the work of the people and the people will be liberated from exploitation and arbitrariness and where conditions for free development will be created for all the nations and nationalities alike (Constitution SFRYof 1974, pg. 7) beginning with the right of the Yugoslavian people for self-determination, up to secession (Constitution SFRY, Introductory Part I, pg. 9), where each and every worker is entitled to rights under the principle "Each according to his abilities - each according to his work" (pg.11), where the power belongs to the working class (IV, pg. 15), where freedoms, rights and duties of the people and the citizens are guaranteed with the constitution, where the right of free thinking was guaranteed (article 166, Constitution SFRY), where arbitrariness of the state organs was considered anti-constitutional and was condemned, (article 198) where the victim restitution was guaranteed (article 199) where the Public Prosecution was the only prosecuting organ against criminal offenders (article 235, Constitution SFRY 1974), where the right of defense was a municipality, province and a task fo the republic to organize its military defense within its territory (article 239), where in the commanding structure of YPA/JAN (Yugoslav People's Army/Jugoslavenska Narodna Armija) the national representation of the republics and autonomous provinces was guaranteed (article 242) and where the use of the languages of all the nations within the YPA was guaranteed (article 243).

But all of this was a Utopia, because the law and the constitution did not apply the same for all in a totalitarian Yugoslavian system, thus the language and education being constitutional categories their exercise in practice was considered a nationalist act if not approved by the party. It was the YPA that besides having "people's and Yugoslavian" in its name, had nothing in common with Yugoslavia (according to data of year 19901992)because its commanding structure consisting 235 generals and admirals only 27 where Croatians (Command of YPA - a criminal organization / Zapovjedni vrh JNA zločinačka organizacija), who forgot the constitutional duties and obligations to defend external borders and involved themselves in the political games led by Milosevic. This involvement of the army in politics caused disgruntlement among the soldiers, particularly among the Albanian recruits who expressed their stances and because of these stances they were subject to different harassments and even physical elimination, their murder by the the army's secret service (KOS - Counterintelligence Service Kontraobavještajna služba) and their return home to Kosovo and beyond to their 
families in coffins. It was this military secret service that committed such murders in Paraqin (the killing of Aziz Kelmendi and five other soldiers of different nationalities) with the sole purpose to mobilize the Yugoslavian opinion to pro-Serbian stances who supposedly where fighting Albanian nationalism. As e result of the anti-constitutional acts, UDBA (State Security Service - Služba Državne Sigurnosti) and the military secret service where the two main levers that represented the institutions that made the law and the trails in Kosovo. With the purpose of creating a safety for the regime and embed fear to all the Albanians in Kosovo who dare to require the advancement of the political status of Kosovo the the rank of Republic (1981), or who opposed the constitutional changes (1989) where it was required from Serbia that the autonomy of Kosovo and Vojvodina be undone, resulted with prosecution, persecution and political isolations. The Public Prosecution as the competent organ was not aware of any of the investigative cases, or ostensibly not aware of the fate of the 237 Albanian citizens sent into Isolation in Serbian prisons (Isolated, pg. 287-293).

\section{The constitutional rights and the state territory in Kosovo 1981 -1989}

The political-constitutional advancement of Kosovo that resulted in the amendments of the Constitution of 1974, affected positively in general progress in the Socialist Autonomous Province of Kosovo. However, these amendments where not seen with a good eye by the Serbian political class who lost the battle of Brijuni in 1966 (the dismissal from duty of Aleksander Rankovic -chief of the federal police) especially after the death of Tito when reorganizations begun. Its economic, political, social and educational development was an obstruction not only for particular circles in Belgrade. Growth of social gross product and national income in Kosovo (Statistical Yearbook of SAPK 1978, pg. 55) employment growth (Statistical Yearbook of SAPK 1978, pg. 49) growth of the average age of population (Statistical Yearbook of SAPK 1978, pg. 48) growth of natality by 28.5 promiles per year (Statistical Yearbook of SAPK 1978, pg. 30) growth of educated persons and lower rates of analphabetism was seen as an expansion of Albanians in the imaginary Serbian territory. The opening of the University of Prishtina and its growth, who in the academic year of 1977.1978 had 40,820 students in 8 faculties, an academy of arts and 9 higher education schools (Statistical Yearbook of SAPK 1978, pg. 313) with 5,414 University professors, 15,782 teachers (Statistical Yearbook of SAPK 1978, pg. 308), 27,018 high school and elementary school students and 140,648 workers employed in different private and social sectors were considered a destabilizing factor. (Statistical Yearbook of SAPK 1978, pg. 51). Despite the small number of employed citizens, consisting of about $10 \%$ of its population and with the lowest income per capita in Yugoslavia, there was a mobilization to continue ambitiously toward a faster economic and political development. This mobilization and this ambition of Kosovo's Albanians was terrified for all who lost the battle in Brijuni in 1966 and who after the death of Tito begun their empowerment and their return to the political scene in Belgrade. As a result of this discontent towards the movements within Kosovo's and Yugoslavian society, the working class, peasant and particularly the student youth went out to open protests and with open demands precisely in defense of the values 
guaranteed with the constitution of SFRY and the constitutional-juridical advancement of SAPK to the status of the Republic within the SFRY.

Such demands for political and constitutional advancement, where demanded by Kosovo's youth peacefully on $11^{\text {th }}, 26^{\text {th }}$ of March and $1^{\text {st }}$ and $2^{\text {nd }}$ of April 1981. The demands of the demonstrators where public, in factories, in workshops, in construction sites, in cooperatives, in villages, neighborhoods, cities, different state institutions, in mines, in schools and the university. And what did these demonstrators who nobody listened to nor wanted to listen to, demand?

In the demonstrations of March 11 th and April $1^{\text {st }}, 2^{\text {nd }} 1981$ and in the demonstrations of march 23 1989 the main slogans carried where "Kosovo's Republic", "We're Albanian not Yugoslavians), (Trepca works Belgrade builds", "Kosovo is of Kosovans" ", "We don't want tanks in the Province, we want the Republic. (", "Constitutional rights by means of freedom or war". But these demands that got presented into streets and city squares of Kosovo were considered as hostile demands, counter revolutionary and as result was followed by SFFRY Leadership announcing state of emergency on $2^{\text {nd }}$ of April 1981 (pg. 18 What is Happening in Kosovo/Sta se dogadja na Kosovu, 1981)

These nationwide demands, where demanded by Kosovo despite being considered counter-revolutionary, irredentist, nationalistic by the regime and with the purpose of destroying the brotherhood and Tito's Yugoslavia! According to the constitution of SFRY these demands turn out to be the opposite but the reawakened Serbian nationalism thirsty for hegemony in the entire Yugoslavia used e Gobble's propaganda against Albanians of Kosovo and Albanians living elsewhere in Yugoslavia with the sole purpose of implementing the infamous elaborations of Garashanin, Qubrillovic, Andriq and of the Serbian Academy (1986) for the creation of the Greater Serbia in the back of Bosnian, Croatian and Albanian land as time would show later. Initially, the main demands of the working class of Kosovo that were heard in the streets of Kosovo where demands for a better life, a demand this guaranteed with the preamble of the Constitution, Chapter I where it says "the working citizens, nations and nationalitiesexercise their rights in the Socialist Republics and Socialist Autonomous Provinces in accordance with their rights ..." (Constitution, 1974, pg. 10) The workers demanded to take power from the communist oligarchs because ... the socialist social organization of the SFRY was based on the power of the working class and all the working people, in relations between the manufacturers, free and equal creators, whose work exclusively served to fulfill their personal needs and the common needs (Constitution, Chapter II, pg. 10) to be followed with demands to stop any exploitation of the human, alienation of the working class and the working people by the manufacturing equipment and other working conditions and in sharing of the work products and social development orientation in self-determination grounds, according to the principle "everyone according to his abilities - each according to his work", that demanded that the goods manufactured in Kosovo and the wealth of Kosovo be used in the interest of its own population.Another slogan that emerged in public "Trepca works, Belgrade builds" was a demand that the requested that the goods of Kosovo be used for its own economic development that also is the base for a democratic development of the society "that gives the person the possibility to achieve his interests, develop his authority in the social political activity, in self-governing organs and in the social political 
organs and organizations (Constitution 1974, pg. 11) The demand "Kosovo of Kosovans" consists on the constitutional right guaranteed in chapter IV where it says "in the SFRY the entire power belongs to the working class in connection with all the working people from the city and village" (Constitution, 1974, pg. 15) Thus, Kosovo was of those who worked and lived in it and therefore should be governed by them. In chapter $\mathrm{V}$ of the constitution the rights and freedoms of the citizen are guaranteed also "every action that impairs these freedoms and rights of the people and the citizen contrary to the interest of the socialist society (Constitution 1974, pg. 18) Article 170 of the Constitution of Yugoslavia guarantees the right of the national declaration of all of its citizensand the demand "we are Albanians not Yugoslavians"was a demand that should have been heard and not be condemned. This right was guaranteed with the Constitution of SAPK in article 4 where it says "in the SAPL the nations and nationalities are equal and have equal rights, to realize the equality of nations and nationalities the right for their free development and free expression of national characteristic, language, culture, history, symbols, was guaranteed. This slogan was intended to inform the wide Yugoslavian opinion that determination of the nationality as "Yugoslavian" created inequality in employment, social rights, student scholarships etc. Because the declaration as "Yugoslavian" was a parenthesis that require that a new nation be created who as always in history past was used for political purposes against Albanians.Strangely this slogan instead of alarming the wide Yugoslavian opinion for violations of the civil and national rights was classified as a nationalistic demand.

The slogan that was being waved in the cities of Kosovo "we don't want tanks in the Province, we want the Republic" had emerged after the so called People's Army of Yugoslavia "JAN" was ordered by the SFRY leadership to go out on the streets of Kosovo and to sow terror, after having declared a state of emergency. Thus, the demand for the removal of the tanks from the streets and cities of Kosovo was in defense of the constitutional order because the security and the borders of SFRY were not threatened from anyone, yet the army had a duty to defend and safeguard only the exterior borders of Yugoslavia and not be involved in matters of the public order.

2. For the killings that took place on March 1981, the international opinion was notified on April $6^{\text {th }}$ by Stane Dollnac (member of the leadership of Yugoslavia) in a conference organized with accredited foreign journalists in Yugoslavia.This announcement came four days after Belgrade had declared a state of emergency in Kosovo and no one had the right to enter nor leave from the Province involved including foreign journalists. (What is Happening in Kosovo/Sta se dogadjalo na Kosovupg.18, 29-39) in this conference, Dollnac inform the international opinion in Kosovo that during these demonstration that where lead by Brussels, Stuttgart and USA-ja and internal enemies of Yugoslavia, 11 persons were killed, but doesn't announce how many where killed and injured in Prishtina. According to him, from these 11 killed citizens, 9 where demonstrators and 2 were police officers. In the conference, Dollnac who then later become the soul of Yugoslavian UDBA in fighting emigration, says that the first two demonstrators were killing in the mob, in the demonstrations organized if Ferizaj and Podujeva and were not shot by the police, thus trying to give a different motive and direction to these killings, by prejudice considering them as criminal acts or with revenge 
motives", meanwhile the others were found dead in the street while 54 other were injured in the village (What is Happening in Kosovo/Sta se dogadjalo na Kosovu,pg.3) Since March 1981 until October 1988 in Kosovo 584,000 citizens have been prosecuted and persecuted as "irredentists" and "counter-revolutionaries"(Kosovo Issue/Kosovsko pitanje, pg. 149)or about 36\% of its entire population in Kosovo, majority of which were students, professors, teachers, intellectuals and other economy directors.

For the military and police violence undertaken by the Belgrade authorities in Kosovo, author Julie Mertus writes, throughout $24^{\text {th }}$ of January to $3^{\text {rd }}$ of February 1989 over 15,000 military troops were engaged in Kosovo (from Nis, Skopje, and Podgorica) and with over 2,000 special forces troops (from Belgrade) engaged in maintain order and tranquility and as a result of the violence exercised against its citizens over 30 citizens were killed and over 110 were injured or wounded (Kosovo; Haw Myths and Tryths Started a war, pg. 187). According to Mertus, beside the military and police violence a political war had begun to "Kosovize" the Serbian politics in Kosove by through the use of Serbian state media with the purpose of Albanian national degradation and the constitutional and juridical degradation of Kosovo itself and the return of its position to the level of a municipality (Kosovo:Haw Myths...pg. 9)

For the violence exercised against Kosovo's citizens by the Serbian authorities, besides the different international factors, NGOs and credible international institutions that deal with human rights cases, the Council for Defending Human Rights and Freedom in Prishtina, who in the spring of 1992 sent a prememory to the Conference of Hague for Yugoslavia, Mr. Carrington, 44 ${ }^{\text {th }}$ Session of the UN Committee for the Human Rights in New York OSCE and the general secretary of UN Mr.BoutrosBoutros Gali(Knocking on Europe's conscience,Letterof 10th June 1992, pg.82). Through this letter, informing in depth for the history of Kosovo since the Balkans wars and forward, its political history, violent taking of the autonomy from Serbia, the destruction of economy, education, health, culture, science, grave social state after the dismissal of Albanians from work and the violation of the right to live. In this prememory this institutions and personalities are informed that beginning in 1981 until 198996 Albanians were killed and over 610 were injured from which 49 of juvenile age.(Knocking on Europe's Conscience, Kosovo, Evidence \& Documents, pg.11 and 27) Only during the protests of March and April of 1980, in 11 cities and 5 villages of Kosovo, 30 citizens from 11 to 54 years of age were killed by the police (Knocking on Europe's Conscience, Kosovo, Evidence \& Documents, pg. 71)

Besides the murder of innocent civilians who demonstrated in the streets of Kosovo, the international factor was notified of another phenomena the killing of Albanian recruits who served in the People's Army of Yugoslavia. In this prememory the number of 54 Kosovo'sAlbanian military troops killed in the Yugoslavian People's Army of is mentioned, who were returned home in in sealed coffins and with documents stating suicide. (Knocking on Europe's Conscience, Kosovo, Evidence \& Documents, pg. 35)The killings of Albanian recruits in YPA and the return of their bodies to their families was a bad omen for Kosovo (Human Rights abuses in Kosovo 1990-1992)who in the first anniversary of the Serbian forces intervention (March 1989) was facing massive poisoning of thousands of high school and elementary school students.(Kosovo: How Myths and Truths Started a War, pg. 187). 
For the killings of the Albanian recruits in the YPA the organization Human Rights Watch makes a report in its report of 1990-1992.(Human Rights Watch,Human Rights abuses in Kosovo 1990-1992). Among the soldiers killed in YPA and classified as suicide by the investigative military organs of Yugoslavia was Jetullah Deskaj, from Siceve village of Klina, killed on 18 $18^{\text {th }}$ ofMay 1990 in Subotica barracks. According to data these "suicides" had always taken place in between 03:00 to 06:00 in the morning, or within the first months of military service. In reality the phenomenon of Albanian soldier's killings in the Yugoslavian army was known to happen before 1981. Thus, after this year, 1981, the number of "suicides" rose, yet no one from their families believed the official military version. For the killed soldier Jetullah Desku (killed 18.05.1990) in the Subotica barracks, his family in Kosovo was notified on 19.05.1990. The lifeless body of the Desku soldier was handed over to his family on 20th of May 1990 when the family is notified that his son had committed suicide. The next day on 21st of May the coffin of Jetullah Desku is handed over to the family who did not allow that the soldiers who were escorting be part of the funeral ceremony. After his arrival in the village, where many citizens had been gathered, in the presence of his family and the Council for Defending the Human Rights and Freedom the sealed coffin is opened and the military uniform removed. After the removal of the military uniform, in his body five wounds caused from bullets are seen (Jetullah Desku - Insatiable Name, pg. 30). According to testimonies of the Council of Defending Human Rights and Freedom in Prishtina in concludes that many of these "suicides" of the Albanian recruits where committed by many bullets and mainly with an entry point of the bullet from the back. According to testimonies so far (which are not definitive) there are 84 soldiers killed during their military service in YPA from 1981 to 1992(Jetullah Desku - Insatiable name,pg.95-99) According to the statistical yearbook of Serbia October 1999, section 3-23 of the dead by disaster, suicide and murder (continued) it writes that in Kosovo in the year of 1991 none had committed suicide, in the meanwhile on 1997 only 4 suicides had been committed. While only 24 citizens had been killed (statistical yearbook of Serbia/ststisticki godisnjak Serbije, 1999, 3.Population). This shows that Serbia had not registered precise data and had manipulated with its official statistics therefore hiding the number 54 of the soldiers that had been officially presented as suicide from Kosovo. After the desolation of Yugoslavia the Bosnian author and ex colonel of YPA Nihat Halilbegoviq, shows that in the so called YPA from the 27th of June 1990 until the end of 1991213 Bosnian recruits who were in military service had been killed. The same author also writes for the investigations of the death of 67 Albanian recruits who were declared as committing suicide. (Mom, I need to give their head: the suffering of soldiers-recruits in the former YPA and their rescue /Mama, moram im glavu dati:stradanje vojnikaregruta u bivsoj JNA I njihova spasavanje, January 2002, Halkomex, Sarajevo,BiH). In his book "Psychology Combat Units/Psihologija borbenih jedinica" the author Petar Kostic mentions the number 168 soldiers killed in YPA within the period of $1981-1986$ but not mention national belongings. He calls the suicide of the 14 Serbian soldiers in 195 a tragedy.In this case he only mentions the percentage of the suicides by dividing them by nationality, where $66 \%$ are Rusyn and Albanians with $0.3 \%$ whom this loaded author with nationalism calls them "shiptari" instead of using the official term of national belonging that is "albanci"(Psychology Combat Units / Psihologija borbenih 
jedinica, pg. 85, 2000, NIC Vojska Beograd 2000). This author does not mention the number of soldier that committed "suicide" in the years from 1986 to 1990, nor the case of Aziz Kelmendi, yet he mentions the factors that effect and lead to such measure, which according to him are drug addiction, alcoholism and family problems. The same author shows precisely that these "suicides" had been committed in the hours after midnight of the hours before morning, in spring and autumn and in rainy days(Psychology Combat Units / Psihologija borbenih jedinica, pg. 89, 2000, NIC Vojska Beograd 2000).

\section{Conclusion}

Since the creation of Yugoslavia (1918) until its desolation and its leave from Kosovo (June 1999), the Albanian element was "wild meat" in its body. Known by the Yugoslavian state (during the period of the Krajl 1918-1939, Titos period 1954-1988 or during the Milosevic period 1989-1999) sometimes like albanci, other times as shiptari, arnauti they were maltreated. This maltreatment came in phases followed by a permanent violence with the sole purpose of ethnic cleansing. During the Serbian Croatian Slovene Kingdom, Albanians were in the brink of physical extinction and the only salvation was emigration from their home to Turkey. The Second World War interrupted briefly the continuity of this project that restarted after the Second World War (1945 - 1966) with the state party and a police state for Albanians there was no freedom. After 1966 (with the fall of the internal minister Rankovic) until the death of the Tito (1980) Kosovo's Albanians breathed more freely, schools had opened and the university in Albanian language, Kosovo got its autonomy (1974) although regarding economy problems were quite eminent and the country was the last regarding investments and economic development. As a result of this negative trend in general economic and political development, on March 1981 in Kosovo discontent lead to massive demonstration. State party, this discontent and the demonstrations by Kosovo's Albanians was considered as nationalist, irredentists and counter-revolutionary therefore for its oppression they used the police and the army. As a result of this violence in Kosovo a state of emergency was declared in which case 11 citizens were killed and hundreds were wounded and injured.

The use of violence against its own citizens who were protesting and demonstrating against their guaranteed by the constitution rights being violated brought a different new reality and an exposure of the Yugoslavian socialism that seen from an outsider showed inner democracy. But, the killings of its own citizens and the failure to hold anyone responsible for these murders and wounds, the organization of trials for the student youth and draconian penalties with political orders for verbal delicts (verbal delict is considered a punishable act) and the jeopardize of the brotherhood in Yugoslavia, was a warning of a totalitarian state who did not care for its own constitution. Even the political differences and the killing of recruits in the YPA were considered as steps to an ethnic cleansing within the army. The fear from these doubtful murders in the military that officially were suicides inseminated fear within the Albanian population and the Albanian recruits itself who in different manners left the country and took the road to migration to the west. Massive poisoning of March and April 1990, the dismissal of 
workers from work, dismissal of judges, police, state administration was a planning of the Serbian and Yugoslavian state leadership for a gentle cleansing of the Albanian factor in Kosovo. Unfortunately, the silence of the political head of the Yugoslavian federation towards the violence used against Albanians in Kosovo and in Yugoslavia and their solidarization with the politics of a strong nationalism lead by Milosevic, paved the road to an extremist totalitarian Serbian nationalism. This approval of Serbian and Yugoslavian violence (in Kosovo special federal forces and Special Forces from other republics were operational) towards Kosovo and its citizens caused an increase in Serbian nationalism who had taken full control of the army, the police and the entire commanding structure of the federation. Surprisingly, none of the federal units had the moral courage to defend and stop the staggering rise of Milosevic who after Kosovo returned with fire and iron to the very same federal units, by killing hundreds and thousands of innocent civilians.

The involvement of YPA in the political disputes and their bias position towards Serbia and Serbians, was one of the main key factors of this bloodshed. Serbia and its expansionist politics, in these areas, solely during the past century has spilled blood four times in the Illyricum (1912-1913, 194-1918, 1941-1945, 1990-1999) The previous massacres of the past wars were repeated in the whole territory of the Yugoslavian federation, starting from Dubrovnik, Vukovar, Srebrenica, Prekazi, Izbica, Reqaku and Meje e Kosoves. All of this as a cause of a political adventurer against whom no one had the intellectual nor the political power to oppose when he in an anti-constitutional manner destroyed the autonomy of Kosovo. Although these events had to happen because in totalitarian states where the constitution is just a written paper and the human rights and freedoms of the citizen are the will of a political leader, it is the only way. State terrorism used against its own citizens has its own receipt that being self-destruction. This whole chain of crimes begun and ended in the basis of creating a false Serbian review for allegedly the endangerment of Yugoslavia by Albanian nationalism, when in fact this was a manner of creating a false environment for Albanians with the purpose to realize the memorandum project (1986) for the Greater Serbia. For the use of lie and deceit with the purpose of creating a different opinion, the father of the Serbian nation Dobrica Cosic said: The lie (deceit) is a Serbian state interest. We lie to deceit ourselves, condolence others, we lie out of compassion, we lie out of shame, we lie to encourage, we lie to hide our own misery, we lie out of honesty. We lie for freedom. Lying is a form of Serbian patriotism and confirmation of birth intelligence. We lie creatively (original), imaginary and inventively. And on these inventively Serbian lies hundreds and thousands of civilians from different nations and nationalities were killed and disappeared, Serbia impoverished, Serbian people was crippled, the Serbian vozd died in the Hague prison and the lies are in the anteroom of history waiting that new and inventive lies be knitted.

\section{References}

Constitution of SFRY Official Gazette nr.9/1974 / Ustav SFRJ sluzbeni list br. 9/1974

Constitution of SAPK, Official Gazette nr. 4/1974

Bytyci, Jusuf, Jetullah Desku - Insatiable Name, 2005, Prishtina, Drini -Graf / Bytyci, Jusuf, Jetullah DeskuEmer i Pashuar, 2005, Prishtine, Drini -Graf 
Horvat, Branko, Kosovo Issue, 1989, Zagreb, Globus / Horvat, Branko, Kosovsko pitanje, 1989, Zagreb, Globus

Knocking on Europe's Conscience, Kosova Evidence \& Documents, Council for the Defence ofHuman Rights and Freedoms in Prishtina,Prishtina 1992

What is happening in Kosovo, May 1981, BIGZ, Belgrade / Šta se događalo na Kosovu, Maj 1981,BIGZ, Beograd

Julie Mertus,Kosovo: How Myths and Truths Started a War, 1999, University of California press, LtD London England

Ante Nazor; Ivan Brigović, Command YPA, January 1990-May 1992 (2011) Zagreb, Croatian Memorial Documentation Center of the Homeland War/ Ante Nazor; Ivan BrigovicZapovjedni vrh JNA : siječanj 1990.-svibanj 1992. (2011).Zagreb, Hrvatski memorijalno-dokumentacijski centar Domovinskog rata

Petar Kostic, Psychology Combat Units, 2000 NIC / Army, Belgrade, Serbia / KosticPetar, Psihologija borbenih jedinica 2000, NIC / Vojska, Beograd, Srbija

Yugoslavia, Human Rights Watch, Human Rights abuses in Kosovo 1990-1992 https://www.hrw.org/reports/1992/yugoslavia/seen 26.12.2015

Zvonimir Despot Command YPA - a criminal organization / Zapovjedni vrh JNA - zločinačka organizacija $\quad \underline{\text { http://blog.vecernji.hr/zvonimir-despot/zapovjedni-vrh-jna-zlocinacka- }}$ organizacija-953 pare me daten 28.03 .2016

Dobrice Ćosića: "A lie is a Serbian national interest"/ „Laž je srpski državni interes“

https://crnogorskapitanja.wordpress.com/2013/04/05/priznanja-dobrice-cosica-laz-je-srpski-drzavniinteres/seen 03,04.2016 